\title{
GEOMORPHOLOGICAL RECONNAISSANCE OF THE PSATHOPYRGOS AND RION-PATRAS FAULT ZONES (ACHAIA, NW PELOPONNESUS)
}

\author{
Palyvos N. ${ }^{1\left(^{*}\right)}$, Pantosti D. ${ }^{1}$, Stamatopoulos L. ${ }^{2}$, De Martini P. M. ${ }^{1}$ \\ ${ }^{I}$ Istituto Nazionale di Geofisica e Vulcanologia, Sez. Sismologia e Tettonofisica, Active Tectonics \\ Group,palyvos@ingv.it,pantosti@ingv.it,demartini@ingv.it \\ ${ }^{2}$ University of Patras, Faculty of Geology, leonstan@upatras.gr \\ (*) now at Harokopio University, Geography Department, palyvos@hua.gr
}

\begin{abstract}
In this communication we discuss reconnaissance geomorphological observations along the active Psathopyrgos and Rion-Patras (NE part) fault zones. These fault zones correspond to more or less complex rangefronts, the geomorphic characteristics of which provide hints on the details of the fault zone geometries, adding to the existing geological data in the bibliography. Aiming at the identification of locations suitable or potentially suitable for geomorphological and geological studies for the determination of fault slip rates in the Holocene, we describe cases of faulted Holocene landforms and associated surficial deposits. We also discuss problems involved in finding locations suitable for geological (paleoseismological) studies for the determination of the timing of recent earthquake ruptures, problems due to both man-made and natural causes.
\end{abstract}

Key words: Tectonic geomorphology, Fluvial geomorphology, Morphotectonics, Earthquake Geology, Paleoseismology.

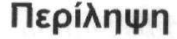

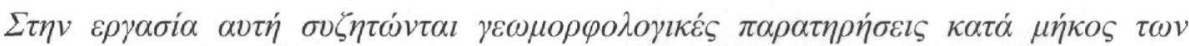

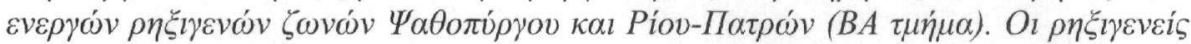

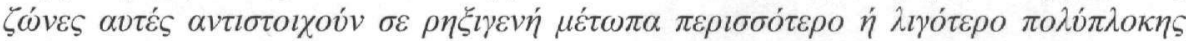

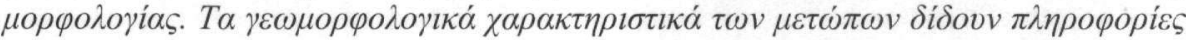

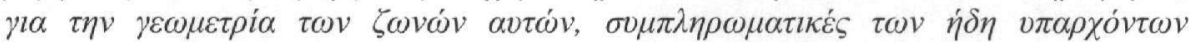

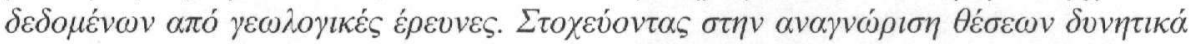

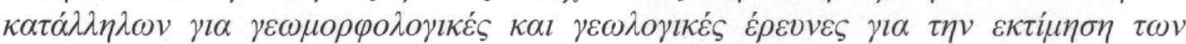

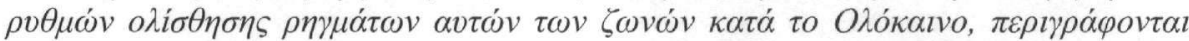

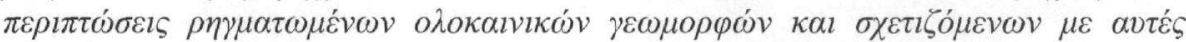

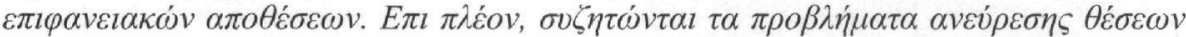

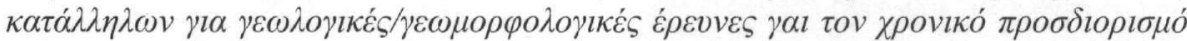

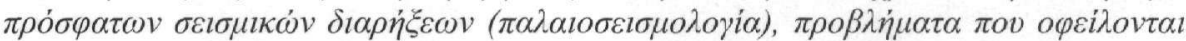

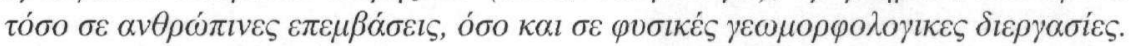

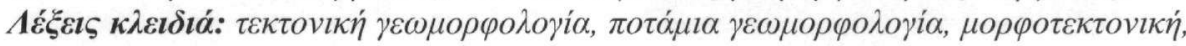

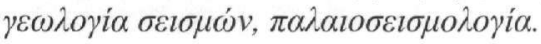




\section{Introduction}

In this communication we discuss reconnaissance geomorphological observations along parts of the Psathopyrgos (Rodini) and Rion-Patras fault zones (Doutsos et al. 1985, Doutsos et al. 1988, Doutsos and Poulimenos 1992, Kontopoulos and Zelilidis 1997, Koukouvelas and Doutsos 1997), at the Rion Straits and its junction with the western termination of the Corinth Gulf (Fig. 1 and its inset). Geomorphological observations can add to the existing knowledge on active faulting, in different ways: by providing hints on the details of the geometry of fault zones (e.g. identifying poorly exposed faults), by sorting out faults that even though active in the Pleistocene (Early, Middle) have been inactive or of minor displacement rates in the Late Pleistocene and Holocene, by identifying faults that have affected Holocene landforms and associated deposits, and by providing constraints on fault slip rates by means of dating of displaced geomorphic markers.

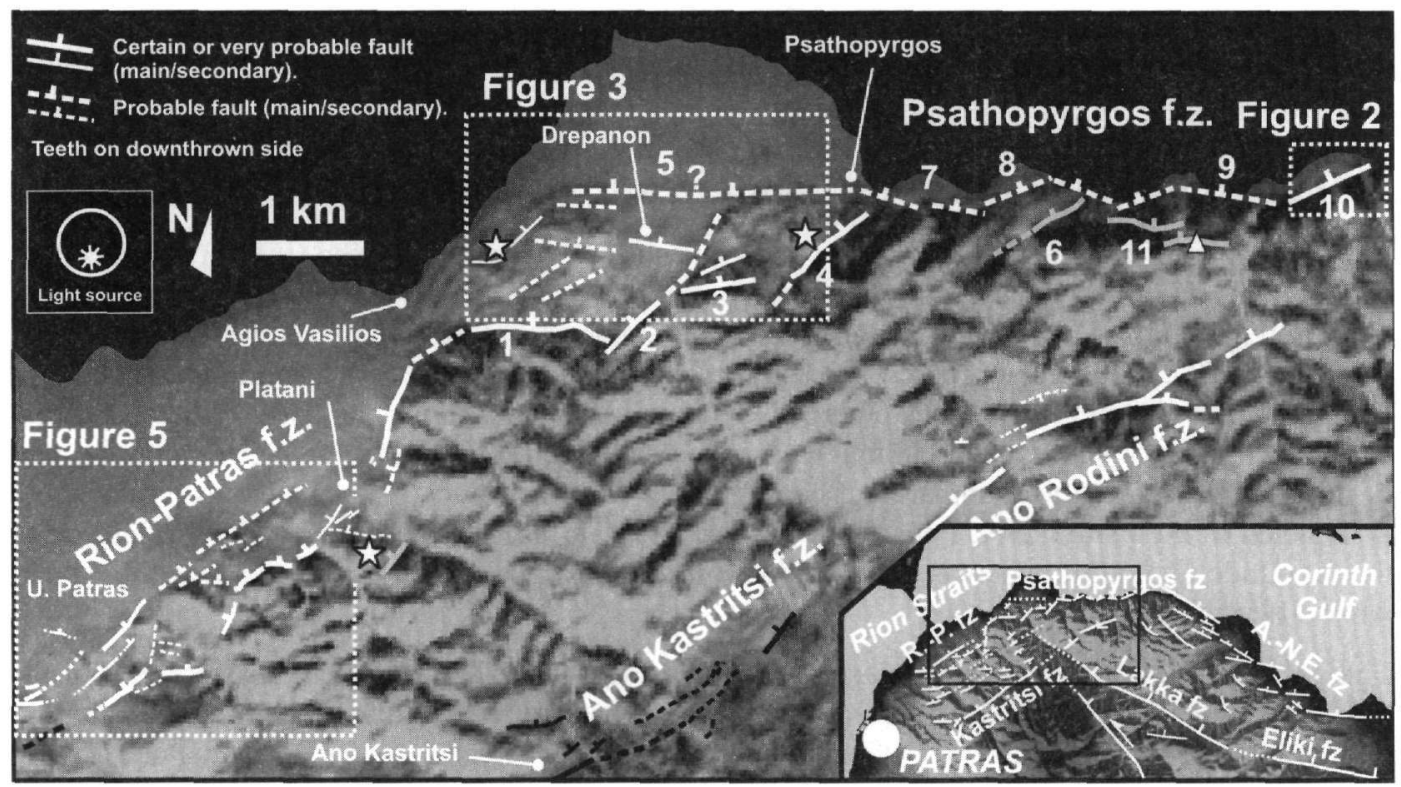

Figure 1 - The complex geometry of the active Psathopyrgos and Rion-Patras fault zones. Fault traces are inferred based on geomorphic and lithological discontinuities. The map (and inset) contains faults previously known from geological studies (Tsoflias and Loftus 1971, Doutsos et al. 1988, Doutsos and Poulimenos 1992, Kontopoulos and Zelilidis 1997, Koukouvelas and Doutsos 1997, Flotte et al. 2005). Only faults active after the latest Middle and Late Pleistocene are depicted (with the exception of the Ano Kastritsi f.z.). Secondary faults on the footwall of the Rion-Patras fault zone are omitted (see bibliography above and Palyvos et al. 2007, this volume). Maps of lineaments in aerial photographs and other remote sensed data can be found in Doutsos et al. (1985) and Stournaras et al. (1998)

Extensive mapping of neotectonic faults in the area in Figure 1 has been carried out by Doutsos et al. (1988) and Doutsos and Poulimenos (1992) who identified recent (post Middle Pleistocene) activity on faults of diverse orientations., whereas additional structures have been proposed by Kontopoulos and Zelilidis (1997) and Koukouvelas and Doutsos (1997). The aims of our reconnaissance were: a) to complement existing data on the pattern of faults that have been active after the latest Middle and Late Pleistocene (roughly, the last $200 \mathrm{ka}$ ) (Fig. 1 contains only such faults, several of which exist in the maps of previous works mentioned above) and, b) to identify faults affecting Holocene landforms and deposits, for the purpose of finding locations suitable for geomorphological studies to estimate fault slip rates during the Holocene and, for geological studies to determine the timing of past earthquakes (paleoseismological studies, and in specific, sites suitable for fault trenching). Paleoseismological trenching studies have been carried out in the broader area 
in recent years, their majority concerns the Eliki fault (e.g. Pavlides et al. 2004, Koukouvelas et al. 2005, McNeil et al. 2005), the fault for which the relatively most detailed paleoseismological record has been obtained so far (see e.g. Koukouvelas et al. 2005). Paleoseismological information is also available for the Aigion fault (Pantosti et al. 2004) and one of the coastal faults immediately to its NW (Palyvos et al. 2005), but we are still far from a satisfactory record of wellconstrained Late Holocene earthquakes. Farther West, there are no paleoseismological data available.

Study Methods. Our reconnaissance included geomorphological observations in the field, on aerial photographs of 1:15,000 scale and on high resolution DEMs constructed from 1:5,000 HAGS maps, detailed topographic surveys and, observations in two exploratory trenches excavated across possible tectonically-controlled surface features.

The reader may refer to Palyvos et al. (2007, this volume) and the references therein for additional information on the geological setting of the area (other than the information included in the following).

\section{Psathopyrgos fault zone (eastern and central part)}

The Psathopyrgos (or Rodini) fault zone (Psfz) has an E-W general direction (Fig. 1) and it is considered to be a presently active structure bordering to the south the westernmost part of the Gulf of Corinth (e.g. Doutsos et al. 1988, Doutsos and Poulimenos 1992, Koukouvelas and Doutsos 1997, Flotte et al. 2005). Its geomorphic expression is clear, a steep, up to $500 \mathrm{~m}$-high coastal escarpment where Mesozoic bedrock has emerged. The fault zone runs along the base of the coastal escarpment, but an offshore, parallel branch has also been identified. Piper et al. (1990), at the E part of the Psfz, a well-defined submarine escarpment with a base around $0.5 \mathrm{~km}$ away from the shore is depicted in the bathymetry. Papanikolaou et al. (1997) trace the respective offshore fault up to the longitude of Rodini, whereas Sakellariou et al. (2001) trace it a bit farther west, with a somewhat different geometry.

The possible faults we draw with question marks in Figure 1 at the central and eastern part of the Psfz, are drawn along the base of escarpment facets that are identifiable in 1:5,000 scale topographic maps of the Hellenic Army Geographical Service (H.A.G.S.). Question marks are used to stress that their exact traces are not well-determined (buried by fan deltas or underwater). The probable trace of fault 8 , drawn on geomorphic grounds, coincides with a contact (tectonic?) between scree and bedrock limestones that is exposed at a coastal cliff along the present coastline. Indications favouring the interpretation of fault 7 as a recently active structure are the presence of a young, suspended strath terrace (covered by a couple of $\mathrm{m}$ of torrential deposits) at the mouth of the valley cut into the escarpment at this longitude, as well as a $2,2 \mathrm{~m}$ high knick-point $50 \mathrm{~m}$ behind. The inferred probable active fault traces at the base of the escarpment along stretch A-B compose a very regular zig-zag pattern with an alternation of faults striking $\sim \mathrm{N} 66^{\circ} \mathrm{E}$ and N98$105^{\circ} \mathrm{E}$. This pattern compares well with the wavy fault zone trace in Koukouvelas and Doutsos (1997). Secondary fault splays (11, drawn in gray in Fig.1) that may be hosting minor or even appreciable displacements also today, are found also higher on the escarpment (mapped in Doutsos et al. 1988, Koukouvelas and Doutsos 1997). One of these faults is associated with an imposing waterfall (knick-point) several tens of m high (triangle in Fig. 1).

Identifying direct geomorphic evidence of recent (Late Holocene) faulting on land along the central and eastern part of the Psfz escarpment is generally hampered by modification by man (highway, old national road, railway and smaller dirtroads), lack of appropriate exposures along most of the zone's length, and dense vegetation. Burial of geomorphic evidence of recent faulting is probable at the small fan-deltas that have developed in front of the coastal escarpment. 


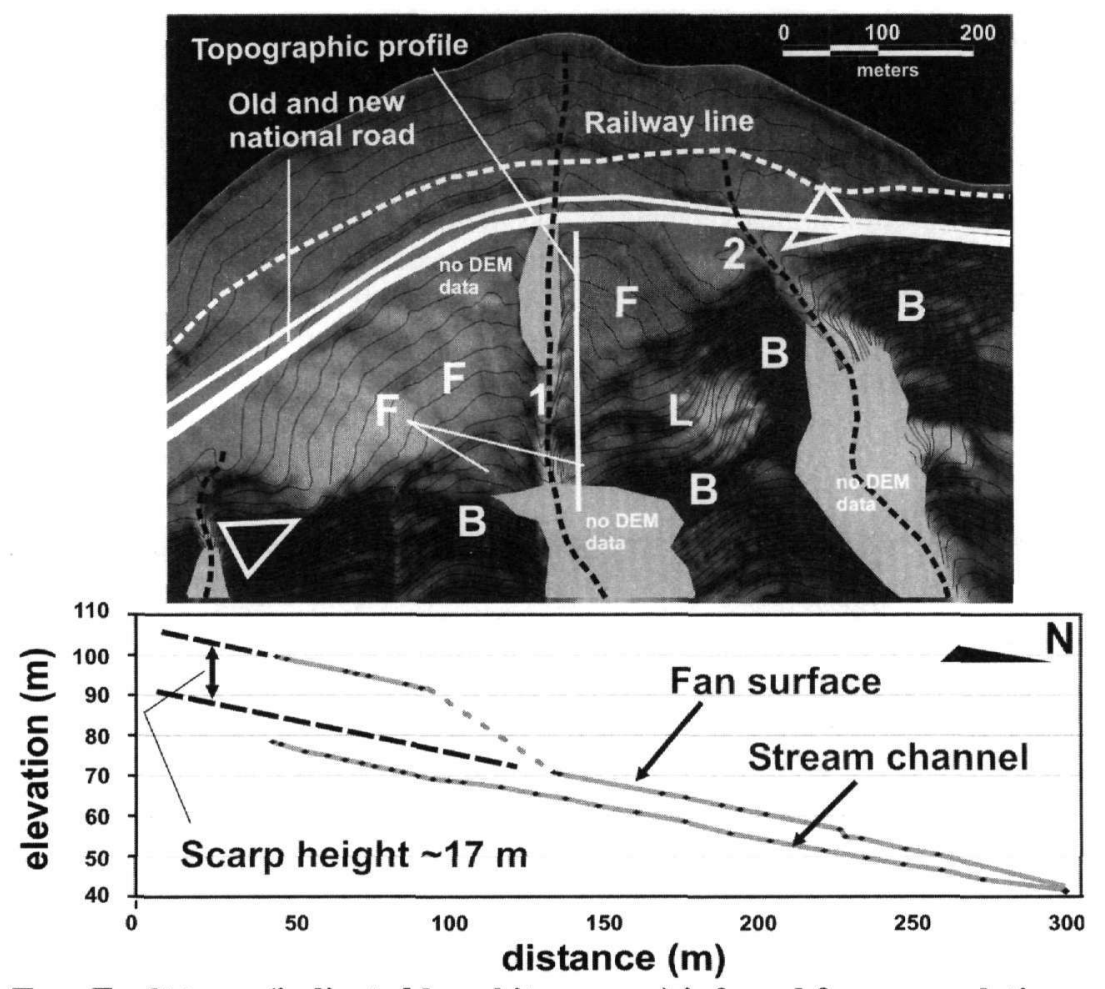

Figure 2 -Top: Fault trace (indicated by white arrows) inferred from cumulative scarp acros $s$ the apex of a Holocene fan at Panagopoula. Map location in Figure 1. F: fan deposits, L: la ndslide, B: Mesozoic Carbonate Bedrock. Contours every 4 m (from 1:5,000 H.A.G.S. topogr aphic diagrams). Bottom: Topographic profiles across the scarp and along the stream chann el, from field topographic survey (gray lines). Black dots indicate surveyed points, elevations refer to arbitrary datum (not mean sea level). The scarp height is estimated to ca. $17 \mathbf{~ m}$

At one case only, we identified geomorphic indications of an onland splay of the Psfz cutting across one of the small fan deltas that are found in front of the bedrock coastal escarpment (Panagopoula fan, fault 10 in Fig. 1 - detail in Fig. 2). The fault at the Panagopoula fan is inferred from its distinct geomorphic signature as a straight, steep scarp across the fan apex (max. height $17 \mathrm{~m}$ ), aligned with the bedrock fault escarpment and, possibly with a second fault strand behind it. The stream that built the fan delta has down-cut inside it, exposing the stratigraphy across the fault zone. The coarse and very poorly stratified nature of the fan deposits, together with sliding along the fault trace did not permit us to directly identify the fault in the existing large outcrop ( 1 in Fig. 2). Dense vegetation and sliding on the E side of the channel, and modification of the scarp into terracettes on the W side, did not allow us to look for geomorphic evidence or recent ground ruptures. At location 2, the bedrock/Quaternary contact is ill-exposed, not permitting a conclusion as to whether faulting has affected the recent Holocene deposits visible in the outcrop or, if they are just onlapping the bedrock (burying the fault).

If the fan surface is assigned a maximum age of ca. 6.5-8.0 ka (the time when sea-level rise decelerated and world-wide progradation of deltas and fan-deltas was possible - e.g. Stanley and Warne 1994), we obtain a minimum slip rate of the order of 2.45-3.02 mm/yr, assuming a fault dip of $60^{\circ}$ (based on observed fault dips at the broader area). This is a minimum for both the specific fault (because the scarp height may represent a minimum for the true displacement and also because a maximum age for the displaced surface is used) and also the Psfz as a whole (there are active faults of the Psfz also offshore - e.g. Papanikolaou et al. 1997, Sakellariou et al. 2001). 


\section{The intersection of the Psathopyrgos and Rion-Patras fault zones}

At the area where the Psfz intersects with the NE-SW Rion-Patras fault zone (RPfz - Doutsos et al. 1985, 1988, see also next section), Late Quaternary deformation is distributed in several NESW and roughly E-W faults. Faults 1-4 in Figure 1 (most traced also in Doutsos et al. 1988) are inferred based on abrupt lithological changes across them and their distinct geomorphic signatures. In specific, they are associated to the relatively higher escarpments in the area, consisting of the oldest Pleistocene fill (1-3) or Mesozoic bedrock (4). Flotte et al. (2005) document a fault plane along f.z. 4, with striae indicating a dextral and dip slip movement, which reflects the character of the RPfz as an oblique-slip transfer zone between the Corinth and Patras rifts (e.g. Doutsos et al. 1988, Flotte et al. 2005). A fault zone with the same strike as 4 has been mapped farther $\mathrm{E}$ in the IGME geological map (fault 6 - Tsoflias and Loftus 1971), juxtaposing different Mesozoic carbonates.

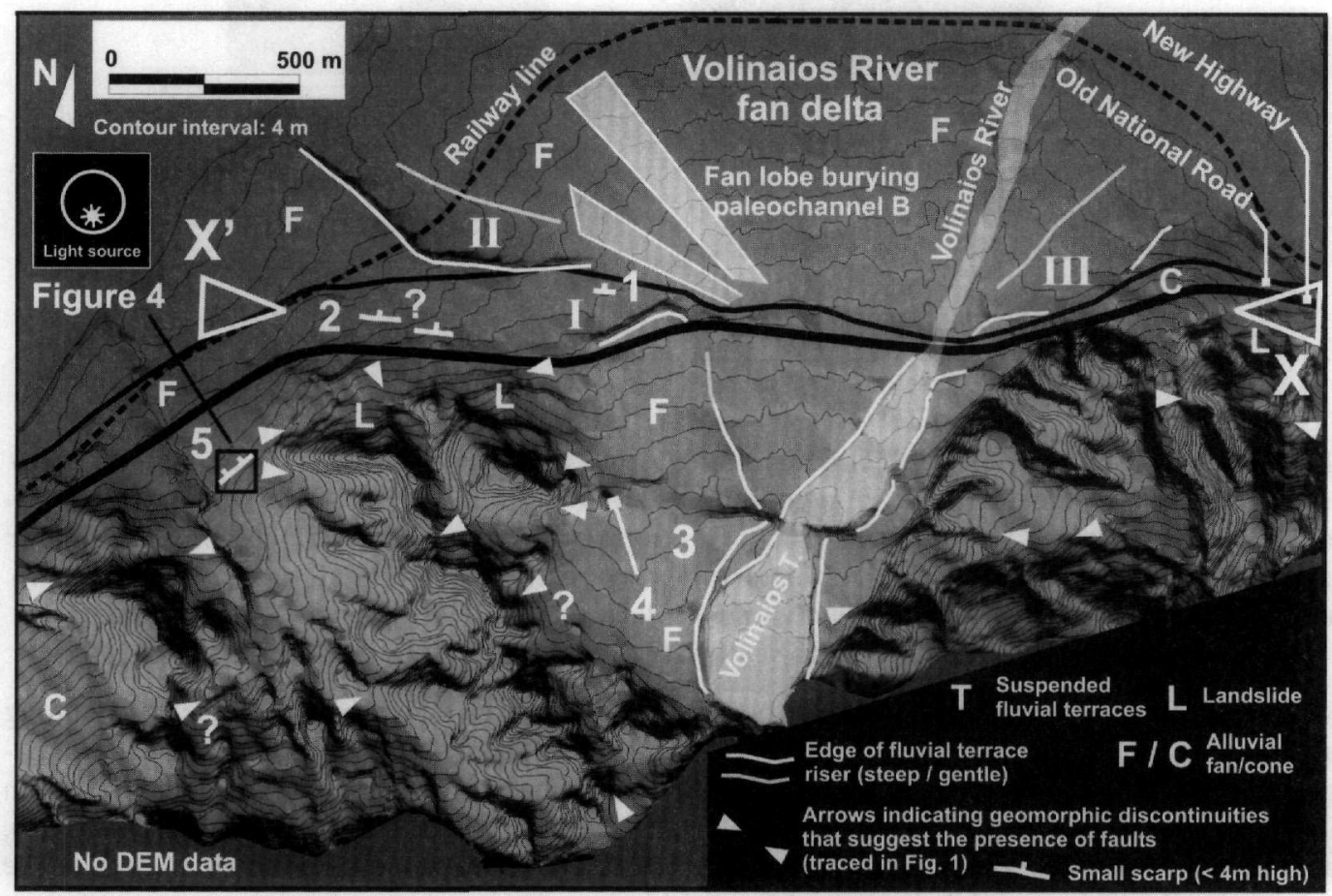

Figure 3 - Detailed morphology at the western part of the Psathopyrgos fault zone, depicted by contours every $4 \mathrm{~m}$ from HAGS 1:5,000 topographic maps and a hillshaded DEM constructed from these contours. Small ( $<4 \mathrm{~m}$ high) scarps (possible tectonic scarps) are indicated by toothed line, larger geomorphic discontinuities indicative of faults are indicated by arrowheads (fault traces in Fig. 1)

The fact that at the hangingwall of faults 1-4 late Middle Pleistocene marine deposits (ca. $170 \mathrm{ka}$, and probably also Late Pleistocene) are found uplifted above sea level (Houghton et al. 2003, Stamatopoulos et al. 2004), suggests that faults also to the north of these deposits are expected. In small scale maps Sakellariou et al. (2001) and Flotte et al. (2005) trace a probable prolongation of the Psfz north of the Drepanon village, whereas Houghton et al. (2003) to its south. In Figure 1 we have drawn a crude trace of a probable E-W fault zone at the prolongation of the general trace of the Psfz (fault trace 5, coincident with the trace of Flotte et al. 2005), along the abrupt, linear northern limit of the lowlands where the aforementioned uplifted marine deposits emerge (zone X$\mathrm{X}^{\prime}$ in Fig. 3, discussed in more detail later). The fact that the uplift rates estimated from the marine deposits at Drepanon, at the hangingwall of faults 1-4 (0.6-0.8 mm/yr, Houghton et al. 2003, Sta- 
matopoulos et al. 2004) are substantially lower than uplift rates on their footwalls (see review and new data in Palyvos et al. 2007, this volume), indicate that also faults 1-4 have been active in the Late Pleistocene, in the context of distributed deformation mentioned at the beginning of this section. We do not have conclusive observations regarding their activity in the Holocene though.

At a closer look, the probable fault zone trace 5 in Figure 1 at the eastward projection of the main trace of the Psfz, corresponds to zone $\mathrm{X}-\mathrm{X}^{\prime}$ that is indicated by large arrowheads in Figure 3. Zone $\mathrm{X}-\mathrm{X}^{\prime}$ is occupied by the old and new national road, partly the railway, villages, sparse houses, cultivation terracettes and secondary roads, features that do not leave a lot of space for identification of geomorphic evidence of Holocene faulting. There has been also important, very recent, intense natural modification (fluvial erosion) along the probable fault zone trace $X-X^{\prime}$, as indicated by well-preserved paleochannels and terrace risers of the large torrent Volinaios (I, II and III, from relatively older to more recent). Furthermore, judging from the fact that paleochannel II (which has a southern edge $10 \mathrm{~m}$ high) is completely infilled by a lobe of the Volinaios fan (Fig. 3), the sedimentation rate on the fan should be quite high. Thus, subtle features as coseismic fault scarps would be easy to bury, even if they had formed recently (in the last 300 years e.g.). Indirectly, we may note that the well-preserved part of terrace riser that indicates the southern edge of paleochannel I, suggests that the latter channel made a conspicuously steep turn upon intersecting zone X-X', a fact that may be due to fault control (see e.g. Pavlides et al. 2004, for example farther E). The same may be true also for channel II, whereas another indication may be that both risers at the $\mathrm{S}$ side of channels II and I have edges substantially higher than the terrain to the $\mathrm{N}$ of the channels, suggesting down-stepping of the fan surface across these channels, as in the case of the Drepanon scarp discussed later. In one case only, we observed a subtle scarp that appears to be natural ( 1 in Fig. 3, inside Arachovitika village, in front of a school of foreign languages) but, to absolutely exclude the possibility of an old man-made feature degraded to a natural-looking scarp, more data than just surface geomorphological observations are necessary (e.g. geophysical survey or trenching). More so, because the scarp is relatively near to the high terrace riser to the south of channel II, and thus there is some probability that it may correspond to gravitational failure. At location 2, scarps that could originally be tectonic have been reworked to terracettes by man. Here also, because of the ambiguities associated with the surface geomorphological evidence, the presence or not of an active fault zone that has affected the Holocene deposits of the Volinaios fan delta needs to be checked by geophysical studies.

Apart from zone X-X', in the area of the Psfz and RPfz intersection, faults affecting the marine formation at the hangingwall of faults 1-4 (Fig. 1) can be inferred from distinct geomorphic discontinuities in the detailed topography in Figure 3. Some such faults are indicated in Figure 3 (see also Doutsos et al. 1988), and it is certain that more exist in reality, but we would rather not overinterpret the morphological anomalies in the topography (some of which correspond to landslides that may or not be along faults), given that these faults are relatively minor in any case. Of more interest, are two cases of apparently clear geomorphic signatures of faults that affect Holocene and Latest Pleistocene deposits, i.e. cumulative fault scarps, which indicate repeated surface ruptures in the very recent past (Drepanon and german road scarps, 3 and 5, respectively, in Fig. 3).

The Drepanon scarp (scarp 3 in Fig. 3). That scarp 3 is most probably a fault scarp (modified perhaps by recent erosion by the Volinaios torrent along parts of it), is suggested by the following: a) it is conspicuously straight and parallels the direction of known faults, b) a fault with the same strike and down to the $\mathrm{N}$ sense of displacement is visible in outcrop at location 4 in Pleistocene deposits, c) the scarp is recognizable also across the terrace at the E side of the Volinaios channel and it is aligned with an incised stream farther $\mathrm{E}$, and d) the channel of Volinaios R. becomes conspicuously narrower at its intersection with the scarp (possibly due to emergence of a harder, less easily erodible formation). Scarp 3 coincides with one of the structural lineaments identified by Stournaras et al. (1998) in remote sensed data. During field reconnaissance, man-made modification was found to be ubiquitous (the Drepanon village is built on and around the scarp). The scarp 
is up to ca. $7 \mathrm{~m}$ high, but based on surface observations only, we cannot know if and to which extent this height may be the product also of erosion along the fault.

The "german road" scarp (scarp 5 in Fig. 3). Scarp 5 traverses a Holocene fluvial terrace, with a trend perpendicular to the direction of the stream immediately to its SW. The scarp strikes parallel to the RPfz, and it is aligned with a marked deflection of the aforementioned stream (Fig. 3). Based on surface observations alone, it is not possible to understand whether this deflection corresponds to dextral horizontal displacement or not. Scarp 5 parallels the general direction of the RPfz, which is identified as a transfer fault zone of dextral character (Doutsos et al. 1988, Flotte et al. 2005). We cannot confidently place scarp 5 in the context of much longer fault zone, at least not on geomorphic grounds. Erosion and probably also sliding, do not permit us to confidently trace the exact continuation of the scarp 5 fault to the NE and SW. We note that scarp 5 need not correspond to a fault more than a few hundred meters long, given the zig-zag fault pattern that characterises the broader area of the Psfz - RPfz intersection (as suggested by faults 1-4 in Fig. 1), but also the rest of the RPfz (Doutsos et al. 1988 and next section).

Unfortunately, the deposits at the base of the scarp were removed during the construction of a dirtroad by the german army during the occupation of Greece in World War II. The scarp was nonetheless surveyed in detail (topographic map and profile in Fig. 4), because a secondary scarp just $S$ of the main one is preserved. In addition, measuring the scarp height can serve for estimates of the minimum rate of vertical displacement (throw) of the fault. The scarp height being ca. $4 \mathrm{~m}$, it would indicate a min. throw rate of $0.77 \mathrm{~mm} / \mathrm{yr}$ if the terrace is assigned a maximum age of ca. 6000 years (assuming no erosion along the scarp).

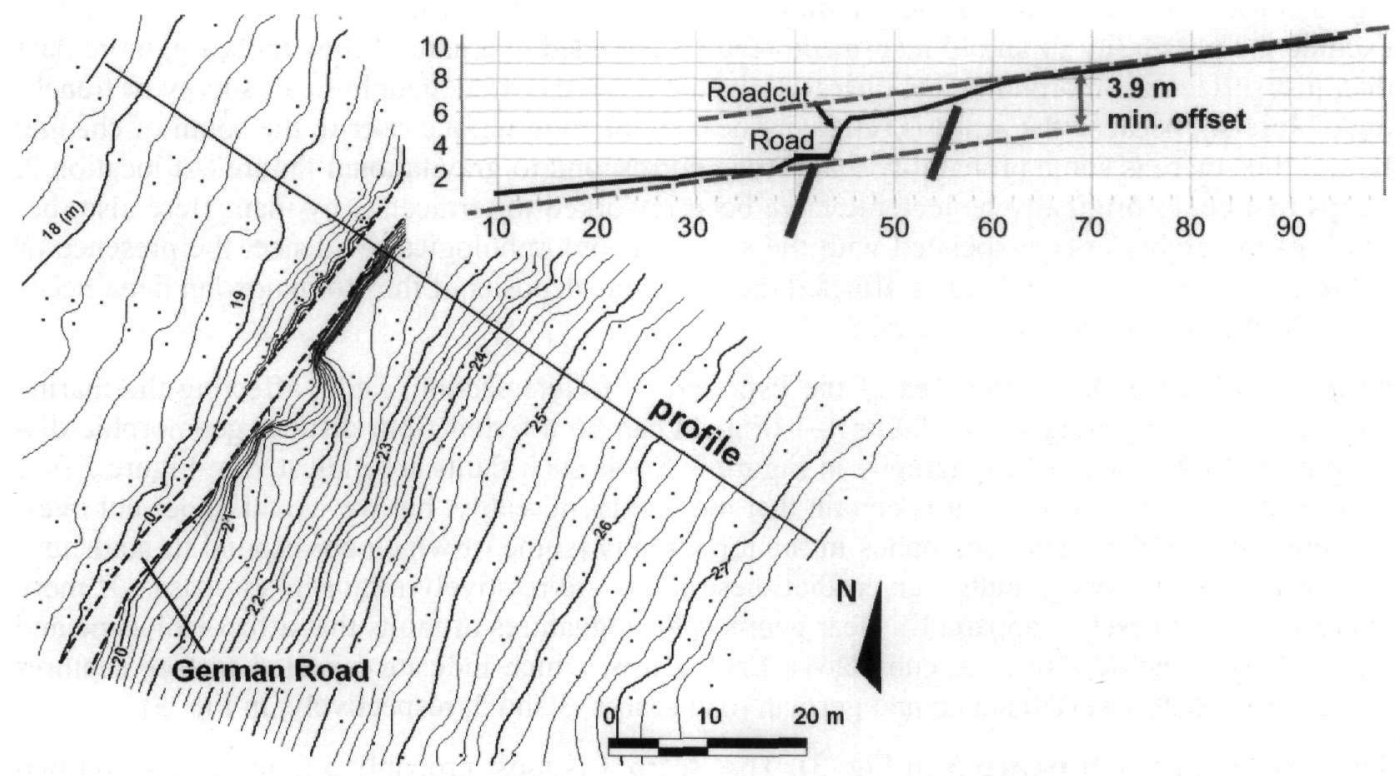

Figure 4 - Very detailed topographic map and profile of the "german road" scarps. Dots indicate surveyed points, contours every $0.25 \mathrm{~m}$. The direction of the arrow pointing to the North is approximate. Elevations refer to arbitrary datum (not mean sea level)

\section{Rion-Patras fault zone}

The Rion-Patras fault zone (Fig. 1) has a NE-SW general direction and extends along the rangefront that is found behind the large alluvial fans of the Rion-Patras coastal plain (Doutsos et al. 1985, Doutsos et al. 1988, Kontopoulos and Stamatopoulos 1990, Kontopoulos and Zelilidis 1997, Flotte 2003, Stamatopoulos et al. 2004, Flotte et al. 2005). The rangefront consists of uplifted 
Early to Late Pleistocene deposits and has a linear general trace when viewed at an appropriately broad scale. Yet, much like the Aigion - Neos Erineos fault system farther E (Fig. 1 inset, see Palyvos et al. 2005 and references therein), at a closer look, the RPfz does not correspond to a welldefined escarpment as e.g. the central and eastern part of the Psfz or the Eliki fault zone farther E (e.g. Pavlides et al. 2004). The rangefront morphology is rather complex, including segments with varying slope orientations. The highest range front slopes reach up to $200 \mathrm{~m}$ high or higher (just $\mathrm{W}$ of fault 1 in Fig. 1). Similarly to the area of the RPfz-Psfz intersection, lowland areas are found in front of stretches of the rangefront, bound by smaller escarpments on their seaward side, a configuration suggesting differential movements of blocks within the RPfz. Smaller faults accommodate the internal deformation of these blocks.

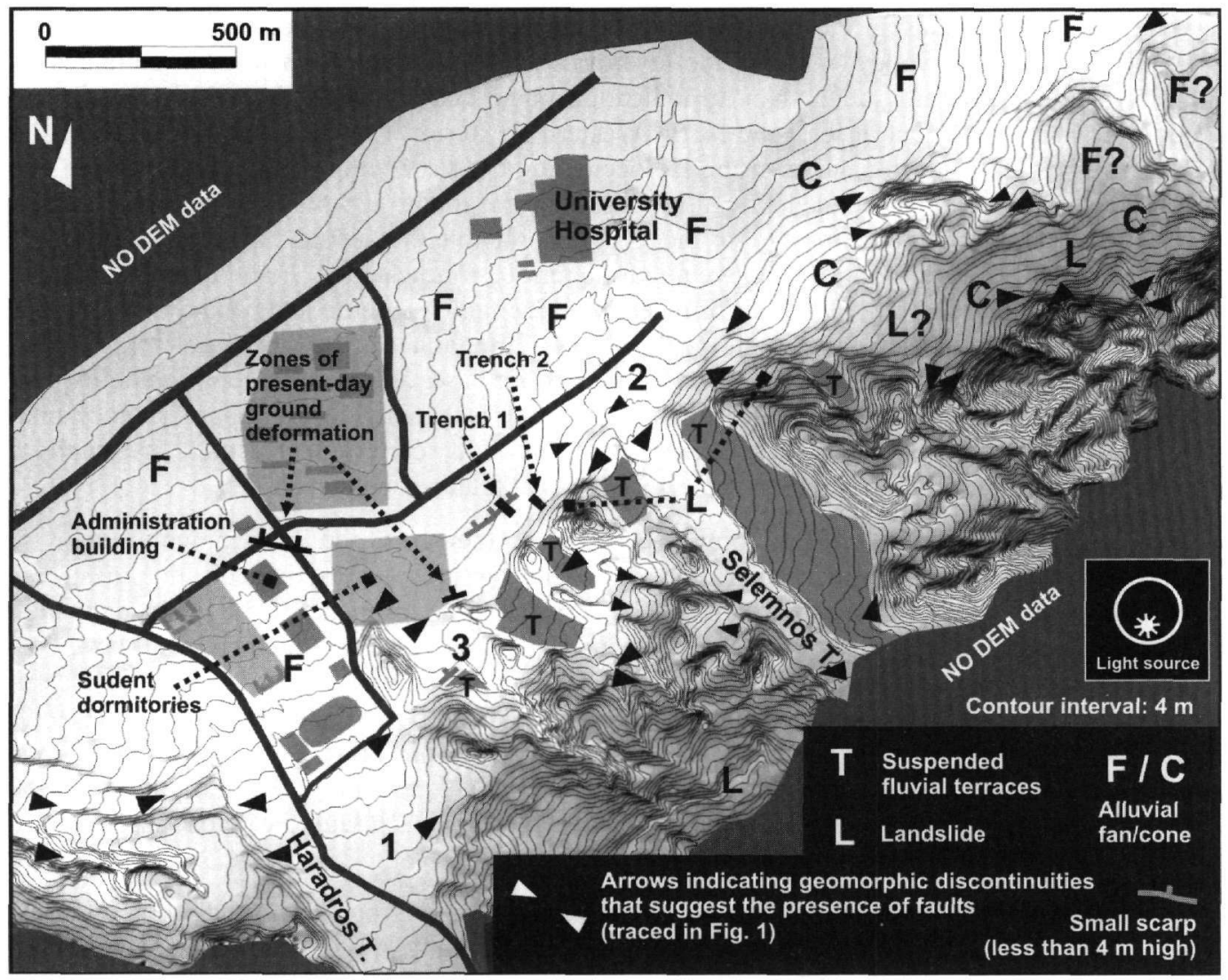

Figure 5 - Detailed morphology along part of the Rion-Patras fault zone at the longitude of the University of Patras Campus, depicted by contours every $4 \mathrm{~m}$ from HAGS 1:5,000 topographic maps and a hillshaded DEM constructed from these contours. Small $(<4 \mathrm{~m}$ high) scarps (possible tectonic scarps) are indicated by toothed line, larger geomorphic discontinuities indicative of faults are indicated by arrowheads (fault traces in Fig. 1)

Although intense erosion and abundant landsliding (Rozos 1991), are not favouring at places the identification of geomorphic discontinuities that correspond to signatures of active faults, it is still possible to identify the general characteristics of the RPfz fault pattern. We repeat that our interest lies in identifying the pattern of faults that have been active in recent times, since the late Middle and Late Pleistocene and, the Holocene. The faults and probable faults in Figure 1 were traced following distinct, straight scarps in Pleistocene deposits or other geomorphic features suggestive of tectonic control (aligned deep saddles at interfluves, stream alignments, drainage anomalies Fig. 5), or were observed in outcrops also. The fault pattern that emerges consists of NE-SW structures with shorter E-W and ESE-WNW faults intervening between them, whereas a third direction 
of faults associated to geomorphic signatures indicating active participation to deformation since the late Middle Pleistocene, is NNE-SSW.

That the RPfz in general has been active since the latest Middle Pleistocene, is testified by the fact that late Middle Pleistocene (MIS 6, ca. $170 \mathrm{ka}$ ) marine deposits have been displaced by faults belonging to the RPfz and found at different elevations, in-between these faults (white stars in Fig. 1, from Houghton et al. 2003, Stamatopoulos et al. 2004 and Palyvos et al. 2007, this volume). In the fault pattern, we do not distinguish faults that have been active in the latest Middle Pleistocene and Late Pleistocene but are not active, or have little contribution in the deformation during more recent periods (the later part of Late Pleistocene and the Holocene). Such a distinction requires more data than those we have at present. E.g. the fact that fault 1 in Figure 5 is associated to downstepping of the topography in Pleistocene deposits, but does not appear to offset the well-defined terrace in the Haradros valley, may be due to erosion and high deposition rates in combination with slow fault throw rate, rather than an indication of no activity in the Late Holocene.Strong geomorphic indications that at least the North-Western ("exterior") faults in the part of the RPfz shown in Figure 5 should be active in the Holocene, are the very young (Latest Pleistocene and probably also Holocene) suspended fluvial terraces that are found in valleys of larger or smaller streams that cross the RP rangefront ( $\mathrm{T}$ in Fig. 5). It is probable that also the apical area of a Late Pleistocene (?) alluvial fan (or, a fan above a marine terrace - indicated by F and question mark in Fig. 5) has been uplifted on the footwall of recently active faults. Kontopoulos and Stamatopoulos (1990) document an important change in the thickness of the fanhead deposits of Selemnos across a NE-SW fault at appreciable distance from the rangefront base, a fault with geomorphic expression on the fan surface. The block model in which this fault is depicted in Kontopoulos and Stamatopoulos (1990) is not in scale (it is schematic) and, the fault scarp indicated there is actually a simplified representation of the zone of "exterior" NE-SW faults discussed above.

As in the case of the Psfz west of Psathopyrgos, also along the part of the RPfz shown in Figure 5, finding geomorphic evidence of recent Holocene ground ruptures is very difficult, due to intense man made modification along most of the RPfz "exterior" escarpments, landsliding and, high deposition rates at the large fans of the Haradros and Selemnos Torrents which can well have buried geomorphic evidence of recent surface ruptures on secondary splays in front of these escarpments (evidence which would be in any case subtle). E.g., Kontopoulos and Stamatopoulos (1990) report $3 \mathrm{~m}$ of alluvium above a Roman bridge at a fan just SW of Figure 5 (1.4-1.74 mm/yr average deposition rate). In addition, the complexity of the RPfz suggests that surface ruptures may be distributed to more than one fault (with smaller displacements in each fault, i.e. even more difficult to preserve in the surface morphology).

Inside the University campus, at two locations recent non-seismic ground deformation is observed on man-made constructions. In front of the administration building, ground subsidence is observed against a roughly ESE-WNW trending discontinuity crossing asphalt roads and pavements (Fig. 5). A similar down to the North deformation has affected a cement wall and road to the $\mathrm{N}$ of location 3 in Figure 5, at a location within the inferred fault zone at the limit between the alluvial fans of the coastal plain and the intensely dissected hills behind them. Whether these phenomena may be due to fault creep or are of gravitational nature (along faults), controlled by hydrogeological conditions, is not known. Similar ground deformation is reported along faults inside the city of Patras by Koukis et al. (2005).

About 70-80 $\mathrm{m}$ in front of the main "exterior" escarpment behind the university of Patras Campus, we mapped a gentle but distinct scarp about $1.5 \mathrm{~m}$ high, that we could follow for a distance of about $150 \mathrm{~m}$ (gray line with teeth in Fig. 5). The direction of this scarp was parallel to the main escarpment and at the projection of escarpment 2 (Fig. 5), suggesting that it could be the geomorphic expression of a secondary fault splay running through Late Holocene deposits in the hangingwall of the main fault zone (a configuration quite common in normal fault zones). Still, based on surface observations alone, we could not absolutely exclude the possibility that the scarp may 
have been a) erosional or, b) an old man-made scarp that was degraded to look like a natural feature.

A point of advantage for potential trenching at this location was that, although the large fans on which the University is built are rich in coarse gravel (Kontopoulos and Stamatopoulos 1990), finer deposits were to be expected here (area in-between two large fans, receiving sediment from much smaller streams draining an area dominated by fine rather than gravel-dominated, coarse Pleistocene deposits). We thus attempted a trench excavation (trench 1), this being the best way to provide a firm answer on the nature of the scarp.

The stratigraphy in trench 1 was examined in detail and indicated that the scarp was not tectonic (i.e. a fault zone was not found in correspondence to the surface scarp morphology). The process that formed the scarp was most probably human modification (construction of a terracette for cultivation). The fluvial deposits exposed in the trench (dominantly fines) contained well-defined coarser layers (sands and fine gravel) that clearly demonstrated the absence of faulting under the surface scarp morphology.

A second, shallower trench (trench 2) was excavated for reconnaissance purposes in front of the base of the main escarpment, across a small and gentle scarplet. The scarplet was also in this case man-made. The trench exposed though reverse faults bringing (Pleistocene?) clays above Late Holocene colluvium (containing ceramic fragments and a filled man-made ditch). This reverse faulting represents the lower part of a landslide that is found on the main escarpment near the trench location (indicated by "L" in Fig. 5). Normal faulting in the Late Holocene deposits that are found below the reverse faults is possible, but further, deeper trenching is necessary for verification.

\section{Discussion and conclusions}

The central and eastern part of the Psathopyrgos f.z. (Psfz) has the relatively simplest geomorphic expression of all fault zones examined. Even so, the geomorphic characteristics of the Psfz escarpment suggest that the Psfz may be characterised by a zig-zag pattern of faults striking $N 66^{\circ} \mathrm{E}$ and $\mathrm{N} 98-105^{\circ} \mathrm{E}$. Geomorphological complexity increases at the area of the intersection of the Psfz and the Rion-Patras f.z. (RPfz), where deformation is distributed in faults paralleling the general directions of both fault zones. Uplifted marine deposits of MIS 6 (ca. $170 \mathrm{ka}$ ) in the Drepanon area occupy a rhomb-shaped block (or blocks) between faults at the Psfz and RPfz intersection, a fact that explains the slower coastal uplift rates estimated there (Houghton et al. 2003, Stamatopoulos et al. 2004), compared to uplift rate estimates to the SE and SW (Stamatopoulos et al. 1994, 2004, see also Palyvos et al. 2007 in this volume).

The RPfz is characterised by geometric complexity also to the SW of its intersection with the Psfz, lacking faults that extend laterally for more than a few km (see also Doutsos et al. 1988), this being perhaps the reason why it is not included a main structure in some maps (e.g., Doutsos and Poulimenos 1992, although it is traced in Doutsos et al. 1985). It may be that after strain migrated to (or was localised at) the RPfz in the Middle to Late Pleistocene, pre-existing Early-Middle Pleistocene structures (belonging to different systems - see Doutsos et al. 1988) were used to accommodate deformation along a NE-SW-trending zone, which extends from Drepanon to the Patras harbour (ca. $15 \mathrm{~km}$ length) - see Doutsos et al. (1988) and Koukis et al. (2005) for fault traces SE of Fig. 1). Apart from active participation, pre-existing structures (e.g. the transverse NW-SE - faults drawn by Kontopoulos and Zelilidis 1997) may be passively responsible for structural discontinuities of the RPfz, acting as barriers associated to step-overs or other geometric complexities.

The recognition of uplifted Late Pleistocene marine deposits on the footwall of the RPfz (Stamatopoulos et al. 1994) indicates that the RPfz should be active also today (see also Flotte et al. 2005). Previous studies have in fact recognised evidence or possible evidence of Holocene activity 
on land at faults belonging to the RPfz (e.g. Kontopoulos and Stamatopoulos 1990). In the part of the RPfz we examined (Fig. 5), such evidence that we identify are the suspended Holocene fluvial terraces. Geophysical surveys appear indispensable to detect active faults possibly buried by the large fans in front of the rangefront (features that surface observations alone cannot detect).

It is probable that the geometry of the RPfz is tending to (or eventually will) be simplified to a straighter NE-SW trace. At the moment though, the data available are not enough to propose that faults inland of the "exterior" ones have been inactive or associated only to minor displacements during the latest Pleistocene and Holocene.

Finding geomorphic evidence of recent (last $2 \mathrm{ka}$ ) ground ruptures along the Psfz and RPfz (and locations suitable for paleoseismological studies) is very problematic, due to intense man-made modification (highway, old national road, dirtroads, villages, buildings and grading of terrain into terracettes for cultivation). Natural geomorphic processes have also caused complications. Fluvial erosion (avulsing channels on fan heads) may have "erased" possible geomorphic evidence of recent faulting, whereas high rates of fluvial deposition at other locations, may have buried such evidence. Gravitational movements along faults that may be inactive in the Holocene are a further factor introducing ambiguity in surface geomorphic evidence.

\section{Acknowledgments}

This work was funded by the "3HAZ Corinth" EU project. We are grateful to G. D' Addezio, S. Pucci, K. Pavlopoulos and V. Mouslopoulou for their work in the UoP trenches. We warmly thank D. Sorel and F. Lemeille for valuable ideas and discussion in the field. We are grateful to the Rector and the staff of the Technical Service of the University of Patras, for giving permission to excavate trenches in the University Campus, as well as the archaeologists and staff of the Ephorate of Antiquities of Patras, for their always positive and prompt responses to our requests for excavation permissions. We also thank IGME, for permission to work in Greece. The original manuscript benefited from the comments and suggestions of $\mathrm{A}$. Michetti and an anonymous reviewer, whom we sincerely thank.

\section{References}

Doutsos, T., Kontopoulos, N., and Ferentinos, G., 1985. Das westliche ende des Korinth-Grabens, N. Jb. Geol. Palaont. Mh., H11, 652-666.

Doutsos, T., Kontopoulos, N., and Poulimenos, G., 1988, The Corinth-Patras Rift as the initial stage of continental fragmentation behind an active island arc (Greece), Basin Research, 1, 177-190.

Doutsos, T., and Poulimenos, G., 1992. Geometry and kinematics of active faults and their seismotectonic significance in the western Corinth-Patras rift (Greece), Journal of Structural Geology, 14 (6), 689-699.

Flotte, N., Sorel, D., Muller, C., and Tensi, J., 2005. Along strike changes in the structural evolution over a brittle detachment faultç example of the Pleistocene Corinth-Patras Rift (Greece), Tectonophysics, 403, 77-94.

Frydas, D., Kontopoulos, N., Stamatopoulos, L., Guernet, C., and Voltaggio, M., 1995. MiddleLate Pleistocene sediments in the northwestern Peloponnesus, Greece. A combined study of biostratigraphical, radiochronological and sedimentological results, Berliner geowiss. Abh. E16:589-605.

Houghton, S.L., Roberts, G.P., Papanikolaou, I.D., and McArthur, J. M., 2003. New 234U-230 ${ }^{\text {Th }}$ coral dates from the western Gulf of Corinth: implications for extensional tectonics, Geophysical Research Letters, 30 (19), 2013. 
Kontopoulos, N., and Stamatopoulos, L., 1990. A stream-flow controlled "wet" Late Quaternary alluvial fan, NW Peloponnese, Greece, Il Quaternario, 3(1), 61-72.

Kontopoulos, N., and Zelilidis, A., 1997. Depositional environments of the coarse-grained lower Pleistocene deposits in the Rio-Antirio basin, Greece. In G.C. Marinos, G.C. Koukis, and S.G.C. Tsabaos (eds), Engineering Geology and the Environment, Proc. Int. Symp., A. A. Balkema, Rotterdam, 199-204pp.

Koukis, G., Sabatakakis, N., Tsiambaos, G., and Katrivesis, N., 2005. Engineering geological approach to the evaluation of seismic risk in metropolitan regions: case study of Patras, Greece, Bull. Eng. Geol. and Env., 28 June 2005, 10.1007/s10064-005-0273-x. (paper online)

Koukouvelas, I., and Doutsos, T., 1997. The effects of active faults on the generation of landslides in NW Peloponnese. In G.C. Marinos, G.C. Koukis, and S.G.C. Tsabaos (eds), Engineering Geology and the Environment, Proc. Int. Symp., A. A. Balkema, Rotterdam, 799-804pp.

Koukouvelas, I., Katsonopoulou, D., Soter, S., and Xypolias, P., 2005. Slip rates on the Helike fault, Gulf of Corinth, Greece: new evidence from geoarchaeology, Terra Nova, 17, 158164.

McNeill, L., Collier, R., De Martini P.-M., Pantosti, D., and D’ Addezio, G., 2005. Recent history of the Eastern Eliki fault, Gulf of Corinth: geomorphology, Paleoseismology and impact on palaeoenvironments, Geophysical Journal International, 161, 154-166.

Palyvos, N., Sorel, D., Lemeille, F., Mancini, M., Pantosti, D., Julia, R., Triantaphyllou, M., and De Martini, P.M., 2007, Review and new data on uplift rates at the W termination of the Corinth Rift and the NE Rion graben area (Achaia, NW Peloponnesus), Bull. Geol. Soc. Gr. (this volume)

Palyvos, N., Pantosti, D., DeMartini, P. M., Lemeille, F., Sorel, D., and Pavlopoulos, K, 2005. The Aigion-Neos Erineos normal fault system (Western Corinth Gulf Rift, Greece): Geomorphological signature, recent earthquake history and evolution, Journal of Geophysical Research, vol. 110, No. B9, B09302, 15pp.

Pantosti, D., De Martini, P. M., Koukouvelas, I., Stamatopoulos, L., Palyvos, N., Pucci, S.,Lemeille, F., and Pavlides S., 2004. Paleoseismological investigations across the Aigion fault (Gulf of Corinth, Greece), C. R. Geoscience, 336(4-5), 335-342.

Papanikolaou, D., Chronis, G., Lykoussis, V., Sakellariou, D., and Papoulia, I., 1997. Neotectonic structure of the Western Corinth Gulf and geodynamic phenomena of the Aigion earthquake, Proc. $5^{\text {th }}$ National Symp. on Oceanography and Fisheries, 415-418.

Pavlides, S., Koukouvelas, I., Kokkalas, S., Stamatopoulos, L., Keramydas, D., and Tsodoulos, I., 2004. Late Holocene evolution of the East Eliki Fault, Gulf of Corinth (Central Greece), Quaternary International, 115-116, 139-154.

Piper, D.J.W, Kontopoulos, N., Anagnostou, C., Chronis, G., and Panagos, A.G., 1990. Modern fan deltas in the western Gulf of Corinth, Greece, Geo-Marine Letters. (10), 5-12.

Rozos, D., 1991. Engineering geological conditions in Achaia Province, PhD Thesis, Department of Geology, University of Patras. (in Greek)

Sakellariou, D., Lykoussis, V., Roussakis, G., and Georgiou, P., 2001. Slope failure phenomena along submarine active faulted slopes: Panagopoula area, W. Gulf of Corinth, Bull. Geol. Soc. Gr., XXXIV/5, 1723-1731. (in Greek) 
Stamatopoulos, L., Voltaggio, M., and Kontopoulos, N., 1994. ${ }^{230} \mathrm{Th} /{ }^{238} \mathrm{U}$ dating of corals from Tyrrhenian marine deposits and the Palaeogeographic evolution of the Western Peloponnesus (Greece), Munster. Forsch. Geol. Palaont., 76, 345-352.

Stamatopoulos, L., Kontopoulos, N., Voltaggio, M., and Branca, M., 2004. Radiochronological data with U/Th method in lagoonal/marine deposits of the NW Peloponnese, Greece. Bull. Geol. Soc. Greece, XXXVI, 1064-1067. (in Greek)

Stanley, D.J., and Warne, A.G., 1994. Worldwide initiation of Holocene marine deltas by deceleration of sea-level rise, Science, 265, 228-231.

Stournaras, G., Tsimpidis, G., Tsoumanis, P., Yannatos, G., and Guillande, 1998. Instability phenomena in the Neogene deposits of Northern Peloponnesus, Greece, Bull. Eng. Geol. Env, $57,65-68$.

Tsoflias, P., and Loftus, D.L., 1971. Geological map of Greece in 1:50,000- Nafpaktos sheet, IGME, Athens. 